\title{
Impact of Biological Agents and Plant Essential Oils on Growth, Quality and Productivity of Cabbage and Cauliflower Plants Correlated to Some Diseases Control
}

\author{
Manal A. Abd Alla* and Fathia S. El-Shoraky** \\ *Cross-Pollinated Vegetables Department, Horticulture Research Institute, Sakha \\ Horticultural Research Station and **Sakha Agriculture Research Station, Plant \\ Pathology Research Institute, Agricultural Research Centre, Cairo, Egypt.
}

\begin{abstract}
CONTROL of the plant diseases using chemicals is one of the most important issues for vegetable crops because of the accumulation of harmful residues of these chemicals sometimes causing serious problems for both human health and agroecosystems. Therefore, a field experiment was carried out during two successive winter years 2014 and 2015 on cabbage and cauliflower plants at Sakha Horticulture Research Station Farm, Kafr El-Sheikh Governorate, Egypt. Different effects of bio-control agent microorganisms and some essential oils on growth, yield, quality and reducing damping-off disease of cabbage and cauliflower plants were recorded. Seven treatments including Bacillus subtillus, Trichoderma harzianum, eucalyptus oil, spearmint oil, clove oil, Rizolex T50 (fungicide) and control were arranged in a randomized complete block design with three replicates. Results revealed significant differences among various growth attributes, total head yield (ton/fed) and head quality due to essential oils and microorganisms. Also, microorganisms and essential oils under field condition improved transplants survive and reduced the damping-off disease incidence as compared to untreated control. Moreover applying of Trichoderma harzianum and Eucalyptus oils seemed to be superior in improving vegetative growth, total head yield with large and heavier heads. As well as, using of clove oil, Trichoderma harzianum and Bacillus subtillus increased shelf life period and decreased cabbage head weight loss percentage, while the superior treatment of cauliflower was Trichoderma harzianum compared to control.
\end{abstract}

Keywords : Cabbage, Cauliflower, Bio-control agent microorganisms, Essential oils, Head yield and quality.

\section{Introduction}

Brassica foods are among the top 10 economic crops in the world (i.e. cabbage, broccoli, cauliflower and Chinese cabbage). These vegetables have been identified as important components of a healthy diet because of their high levels of nutrients and health-promoting phytochemicals (i.e. phenolics, glucosinolates, vitamins and minerals) (Francisco et al., 2017). Among the Brassicaceae, cabbage (Brassica oleracea var. capitata) is regarded as one of the world's leading vegetable crops. Cabbage is one of the most important leafy winter value and high consumers demand, it is commercially cultivated for its large, leafy head that is rich in vitamins, anti-carcinogenic glucosinolates, antioxidant metabolites and amino acids (Park et al., 2014). Cauliflower (Brassica oleracea L. var. botrytis) is another winter vegetables under Egyptian conditions. Cauliflower is grown for clusters of unopened flowers. Beside, its appreciable contents of thiamin, riboflavin, niacin, potassium, magnesium, iron and protein. Also, it has fairly high vitamins $\mathrm{A}$ and $\mathrm{C}$ and folic acid contents (Yamaguchi, 1983). The majorities of cauliflower crop farms are small and situated near to the metropolitan cities owing to high demands for fresh vegetables in these cities. Due to the 
consumer preference for immaculate cabbage and cauliflower, farmers usually used pesticides and fungicides extensively to meet the market expectations (Talekar and Shelton, 1993). Many soil borne fungi play a major role in causing several diseases such as damping-off, root-rot, seed decay, collar rot, crown rot and wilt, etc. Cabbage and cauliflower are attacked by several diseases, mostly caused by fungi and bacteria leading to severe crop losses. Among the fungal diseases, the damping off incited by Rhizoctonia solani, is a major and essentially soilborne pathogen which inflicts heavy seedling losses under favorable condition (Seema and Devaki, 2010). The management of this disease is difficult owing to long saprophytic survival ability of pathogen in soil (Dey, 2005). Control of the plant diseases by chemicals can be spectacular but this is relatively a short term and moreover, the accumulation of the harmful chemical residues sometimes causes a serious ecological problem. Biological control can play an important role in this respect by using plant essential oils and microorganisms. Most of the essential oils are readily available, environmentally safe, less risky for developing resistance in pests, less hazardous to non target organisms and pests resurgence has less adverse effect on plant growth, less harmful to seed viability and quality and above all less expensive (Prakah and Rao, 1997). In this respect, Pereira et al. (2011) reported that, it is possible to use essential oils to control plant diseases. Essential oils could act bio preservatives, reducing or eliminating pathogenic bacteria and increasing the overall quality of animal and vegetable food products (Solorzano - Santos and Miranda - Novales, 2012). Also, the essential oils that are most efficacious against pests are often the most phytotoxic (Lindberg et al., 2000). The essential oils of clove reduced disease severity on tomato plants compared with control, however, application of fungicides against these pathogens may reduce the disease incidence but it is neither cost effective nor environment friendly (Lucas et al., 2012a), although fungicides control of plant diseases is probably the easiest and quickest method of control, but fungicides residues constitute a problem for public health (Wasfi et al., 2016).

Microorganisms have the ability to promote plant growth and to increase productivity and health of plants (Bettial, 1995). Trichoderma spp. is free living fungi that are highly interactive in root, soil foliar and environments (Taylor \& Farncis 1998 and Cumagun, 2012). Trichoderma application onto cauliflower seeds due to in increased the seed germination and improved plant growth vigor as compared to the treatment with fungicide and control (Rehman et al., 2012). In the same line, Trichoderma application onto cabbage seedling increased leaf area, shoot dry weight and root dry weight compared with the untreated control, also in another trial, the yield of lettuce was increased (Rabeendran et al., 2000). Trichoderma significantly enhanced tomato seedling parameters (Azarmi et al., 2011). Trichoderma was effective in the promotion growth and yield of various crops, cucumber (Altintas and Ball, 2005), musk melon )Kaveh et al., 2011), bell pepper (Ball and Altintas, 2006) and strawberry (Elad et al., 2006). From the previous advantages of essential oils and microorganisms in reducing environmental pollution, controlling cabbage and cauliflower diseases as well as producing high quality and safe food Moreover, the bacteria that promote plant growth represent an important segment of these microorganisms by promoting growth, increasing productivity and health of plants (Bettial, 1995).

Therefore, the present work was done to evaluate the effectiveness of Bacillus, Trichoderma, eucalyptus oil, spearmint oil and clove oil for reducing dampingoff, keeping quality, improving yield and prolonging the shelf life of cabbage and cauliflower plants and comparing it with commercial used fungicide

\section{Materials and Methods}

The present study was carried out on cabbage and cauliflower seedlings in the Experimental Farm of Sakha Horticulture Research Station, Kafr ElSheikh governorate, Egypt during two successive winter seasons of 2014 and 2015 to study the effect of plant essential oils i.e., eucalyptus, spearmint and clove oils and microorganisms as Trichoderma harzianum and Bacillus subtillus and Rizolex T50 (tolclophos methyl + thiram) on growth, yield, quality and control of some plant diseases. The soil texture was clay and the mechanical and chemical analysis of the experimental soil was done as shown in Table 1.

\section{Prepared materials for the experiment \\ - Plant essential oils}

The oils (eucalyptus, spearmint and clove) were obtained from a commercial source. It's used as $1 \mathrm{ml}$ of oil/1 water for dipping.

\section{- Production of bio agents}

Fungal production antagonistic was obtained by growing the tested isolates for spore suspension, the tested bio agents individually grew on PDA 
medium at $25 \pm 2{ }^{\circ} \mathrm{C}$ until the abundant heavy growth of conidia was evident. Conidia were harvested by scraping the surface of the colonies with a spatula and then transferred to sterilized distilled water and filtered through nylon mesh. All spore suspensions were adjusted with sterile water to give a spore concentration of $10^{6}-10^{7} \mathrm{ml}$. Meanwhile, bacterial bio agents were grown individually for $48 \mathrm{hr}$ in nutrient broth medium, and then cells were harvested by centrifugation. Bacterial isolates were re-suspended in sterile distilled water and the concentration adjusted to give $10^{9}-10^{10}$ cells $/ \mathrm{ml}$. Roots of cabbage and cauliflower transplants were immersed for 30 min in either fungal or bacterial suspensions then planted in soil plot.

TABLE 1. Mechanical and chemical analysis of experimental soil.

\begin{tabular}{|c|c|c|}
\hline Soil characters & 2014 & 2015 \\
\hline Particle size distribution: & & \\
\hline Clay \% & 53.21 & 49.17 \\
\hline Silt \% & 25.14 & 26.11 \\
\hline Sand $\%$ & 21.65 & 24.72 \\
\hline Soil texture & Clayey & Clayey \\
\hline Chemical analysis: & & \\
\hline pH (1:2.5 soil : water suspension) & 8.05 & 8.20 \\
\hline $\mathrm{EC} \mathrm{dSm}^{-1}$ (soil paste extract) & 2.10 & 2.40 \\
\hline Organic matter content $\left(\mathrm{g} \mathrm{kg}^{-1}\right)$ & 1.70 & 1.60 \\
\hline Available N (mg kg $\left.{ }^{-1}\right)(1 \mathrm{M} \mathrm{KCl}$ extracts) & 36 & 28 \\
\hline Available $\mathrm{P}\left(\mathrm{mg} \mathrm{kg}^{-1}\right)\left(0.5 \mathrm{~N} \mathrm{NaHCO}_{3}\right.$ extracts $)$ & 6.1 & 5.8 \\
\hline Available $\mathrm{K}\left(\mathrm{mg} \mathrm{kg}^{-1}\right)$ (ammonium acetate extracts) & 280 & 214 \\
\hline
\end{tabular}

Seeds of cabbage (Brassica oleracea L. var. capitata) cultivar Brunswick and cauliflower (Brassica oleracea L. var. botrytis) cultivar Amshery were germinated in nursery beds on August $1^{\text {st }}$ in the first season and July $27^{\text {th }}$ in the second one. After two months of sowing the nursery bed seedlings were transplanted into the open field, planted on one side of the ridge at a spacing of $40 \mathrm{~cm}$ within the row on September 31 th and September $27^{\text {th }}$ in the first and second seasons, respectively. The plot area was $16.8 \mathrm{~m} 2$ (8.4 x 2.0), contained 12 ridges of $2.0 \mathrm{~m}$ length and $0.7 \mathrm{~m}$ width, leaving a guard raw between the experimental units.

The treatments were arranged in a randomized complete block design with three replicates. The seedlings of cabbage and cauliflower were dipped in different treatment for 30 minutes, while control seedlings were dipped in distilled water only. The experiment included 7 treatments as follows:

- Bacillus subtillus

- Trichoderma harzianum

- $\quad$ Eucalyptus oil

- $\quad$ Spearmint oil

- $\quad$ Clove oil

- Rizolex T50 (fungicide)

- Control

During the two seasons, seedlings were received calcium super phosphate $\left(15.5 \% \mathrm{P}_{2} \mathrm{O}_{5}\right)$ a rate of $100 \mathrm{~kg} / \mathrm{fed}$ added before planting and ammonium nitrate $(33.5 \% \mathrm{~N})$ at a rate of 100 $\mathrm{kg} /$ fed at two equal doses added before first and second irrigation, respectively. The yield was harvested every three days intervals from $21 \mathrm{st}$ December to $22^{\text {nd }}$ January, and the harvest period included eleven gathers.

\section{The following data was recorded} Horticulture parameters

At harvest period five plants were taken randomly from each plot for measuring following data.

\section{Vegetative growth}

Cabbage growth parameters were done as a number of outer leaves (inedible)/head, weight of inner leaves (edible)/head and leaves dry weight $\%$. Also, Cauliflower growth parameters was done as number of leaves/ plant, leaves weight/ plant $(\mathrm{g})$ and leaf area $\left(\mathrm{cm}^{2}\right)$.

\section{Head yield and head quality}

Average head weight $(\mathrm{kg})$, total head yield (ton/fed) and head diameter $(\mathrm{cm})$ were determined for cabbage plants. Cauliflower parameters were determined as Average head weight (g) and total head yield ton / fed., head diameter $(\mathrm{cm})$ and head height $(\mathrm{cm})$. 
Shelf life period and weight loss \%

Shelf life period and weight loss \% were determined for both Cabbage and Cauliflower heads.

\section{Assessment of disease percentage}

The damping-off disease was recorded at 15 and 30 days after transplanting and percent of disease incidence was calculated using the standard procedure (Hossain 2010).

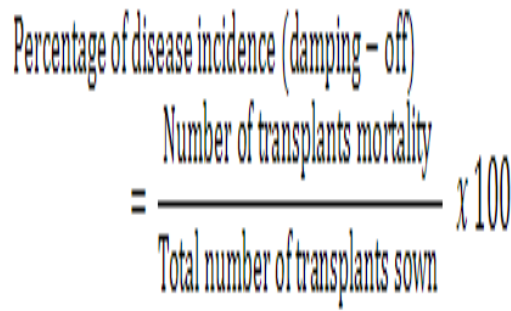

In addition, cabbage and cauliflower plants were also observed for any symptoms of anther disease and severity of these were calculated as percent of diseased area of leaf spot or downy mildew.

\section{Statistical analysis}

Statistical analysis was done as analysis of variance according to Snedecor and Cochran (1990), and the least significant differences (L.S.D. at $5 \%$ level) was used to compare the means value.

\section{$\underline{\text { Results and Discussion }}$}

\section{Horticulture parameters \\ Vegetative growth \\ Cabbage plants}

Essential oils and microorganisms treatments have a significant effect on all vegetative growth parameters of cabbage plants in both seasons (Table 2). The data cleared that, treatment of Bacillus subtillus gave the lowest values of number of inedible leaves/head followed by Eucalyptus oil compared to control and other treatments in both seasons. On contrary, treatments of control, clove oil and spearmint oil gave the highest values of a number of inedible leaves/head without significant differences among them in both seasons. Trichoderma harzianum and Rizolex T50 (fungicide) treatments showed an intermediate values, approximately the same values without significant differences between them in both seasons. Moreover, the highest values of edible leaves weight/ head and leaves dry weight \% were recorded from plants treated with Trichoderma harzianum followed by Eucalyptus oil compared to other treatments in both seasons. Untreated plants had the lowest values of edible leaves weight/ head and leaves dry weight $\%$ in both seasons. These results agree with those of Niakan and Saberi (2009) on phalaris weed who stated that eucalyptus increased root and shoot length. Also, Hassannejad and Ghafarbi (2013) revealed that eucalyptus caused increases in seed germination. Also, Rehman et al. (2012) stated that Trichoderma treatments increased seed germination and improved plant growth vigor on cauliflower.

\section{Cauliflower plants}

It is revealed that, Eucalyptus oil treatment gave the best results concerning number of leaves/plant, leaves weight/plant and leaf area of cauliflower plants followed by Trichoderma harzianum treatment, while the lowest vegetative growth of cauliflower plants recorded by control plants which dipped in distilled water only with significant differences among them in both seasons (Table 3). These results agree with El-Darier (2002) on Vicia faba and Zea mays and Niakan and Saberi (2009) on phalaris weed for eucalyptus. Also, Rabeendran et al. (2000) on cabbage and lettuce and Rehman et al. (2012) on cauliflower for Trichoderma effects.

TABLE 2. Effect of plant essential oils and microorganisms on some vegetative growth characters of cabbage plants in both seasons.

\begin{tabular}{|c|c|c|c|c|c|c|}
\hline \multirow{2}{*}{ Treatments } & \multicolumn{2}{|c|}{$\begin{array}{c}\text { Number of inedible leaves/ } \\
\text { head }\end{array}$} & \multicolumn{2}{c|}{$\begin{array}{c}\text { Edible leaves weight/ } \\
\text { head }\end{array}$} & \multicolumn{2}{c|}{$\begin{array}{c}\text { Leaves dry weight } \\
\text { (\%) }\end{array}$} \\
\cline { 2 - 7 } & $\mathbf{2 0 1 4}$ & $\mathbf{2 0 1 5}$ & $\mathbf{2 0 1 4}$ & $\mathbf{2 0 1 5}$ & $\mathbf{2 0 1 4}$ & $\mathbf{2 0 1 5}$ \\
\hline Bacillus subtillus & $13.3 \mathrm{~d}$ & $13.5 \mathrm{c}$ & $2.41 \mathrm{~d}$ & $2.34 \mathrm{c}$ & $9.40 \mathrm{~b}$ & $9.41 \mathrm{a}$ \\
Trichoderma harzianum & $15.0 \mathrm{~b}$ & $14.9 \mathrm{~b}$ & $2.80 \mathrm{a}$ & $2.71 \mathrm{a}$ & $9.55 \mathrm{ab}$ & $9.45 \mathrm{a}$ \\
Eucalyptus oil & $14.0 \mathrm{c}$ & $13.8 \mathrm{c}$ & $2.62 \mathrm{~b}$ & $2.55 \mathrm{~b}$ & $9.60 \mathrm{a}$ & $9.57 \mathrm{a}$ \\
Spearmint oil & $16.0 \mathrm{a}$ & $15.7 \mathrm{ab}$ & $2.54 \mathrm{c}$ & $2.50 \mathrm{~b}$ & $8.90 \mathrm{c}$ & $8.78 \mathrm{~b}$ \\
Clove oil & $16.0 \mathrm{a}$ & $15.5 \mathrm{ab}$ & $2.46 \mathrm{~d}$ & $2.38 \mathrm{c}$ & $9.00 \mathrm{c}$ & $9.00 \mathrm{~b}$ \\
Rizolex T50 & $15.0 \mathrm{~b}$ & $15.0 \mathrm{~b}$ & $2.40 \mathrm{~d}$ & $2.33 \mathrm{c}$ & $8.70 \mathrm{~d}$ & $8.50 \mathrm{c}$ \\
Control & $16.4 \mathrm{a}$ & $16.5 \mathrm{a}$ & $2.30 \mathrm{e}$ & $2.32 \mathrm{c}$ & $8.52 \mathrm{e}$ & $8.40 \mathrm{c}$ \\
\hline
\end{tabular}

J. Sus. Agri. Sci. Vol. 43, No.1 (2017) 
TABLE 3. Effect of plant essential oils and microorganisms on some vegetative growth characters of cauliflower plants in both seasons.

\begin{tabular}{|c|c|c|c|c|c|c|}
\hline \multirow[t]{2}{*}{ Treatments } & \multicolumn{2}{|c|}{ Number of leaves/plant } & \multicolumn{2}{|c|}{ Leaves weight/ plant (g) } & \multicolumn{2}{|c|}{ Leaf area $\left(\mathrm{cm}^{2}\right)$} \\
\hline & 2014 & 2015 & 2014 & 2015 & 2014 & 2015 \\
\hline Bacillus subtillus & $19.0 \mathrm{~b}$ & $19.2 \mathrm{bc}$ & $1163.1 \mathrm{c}$ & $1100.0 \mathrm{c}$ & $1192.1 \mathrm{~b}$ & $1190.7 \mathrm{~b}$ \\
\hline Trichoderma harzianum & $19.3 \mathrm{~b}$ & $19.8 \mathrm{~b}$ & $1200.5 \mathrm{~b}$ & $1185.0 \mathrm{~b}$ & $1194.3 \mathrm{~b}$ & $1200.3 \mathrm{~b}$ \\
\hline Eucalyptus oil & $22.0 \mathrm{a}$ & $22.3 \mathrm{a}$ & $1350.4 \mathrm{a}$ & $1400.7 \mathrm{a}$ & $1226.7 \mathrm{a}$ & $1286.9 \mathrm{a}$ \\
\hline Spearmint oil & $17.0 \mathrm{c}$ & $17.8 \mathrm{~d}$ & $991.0 \mathrm{f}$ & $1060.3 \mathrm{c}$ & $1070.4 \mathrm{c}$ & $1081.3 \mathrm{~d}$ \\
\hline Clove oil & $18.5 \mathrm{~b}$ & $18.6 \mathrm{~cd}$ & $1090.2 \mathrm{~d}$ & $1085.4 \mathrm{c}$ & $1086.7 \mathrm{c}$ & $1100.5 \mathrm{c}$ \\
\hline Rizolex T50 & $18.7 \mathrm{~b}$ & $19.0 \mathrm{bc}$ & $1010.0 \mathrm{e}$ & $1080.0 \mathrm{c}$ & $1075.6 \mathrm{c}$ & $1090.4 \mathrm{~cd}$ \\
\hline Control & $15.3 \mathrm{~d}$ & $16.4 \mathrm{e}$ & $930.8 \mathrm{~g}$ & $1005.4 \mathrm{~d}$ & $900.5 \mathrm{~d}$ & $960.2 \mathrm{e}$ \\
\hline
\end{tabular}

It is obvious from data in Tables 2 and 3 that, cabbage and cauliflower seedlings dipped in eucalyptus, spearmint and clove oils as well as Trichoderma harzianum and Bacillus subtillus enhanced all vegetative growth parameters compared to the control plants in both seasons. Trichoderma harzianum and eucalyptus oil treatments appeared to be superior in improving vegetative growth parameters of cabbage and cauliflower plants. In generally, the obtained increase in vegetative growth as a result of applied treatments may be due to that Trichoderma spp. can control of minor pathogens leading to stronger root growth and nutrient uptake (Ousley et al., 1993), secretion of plant growth regulatory factors such as phytohormones (Windham et al., 1986 and Baker 1988) and release of soil nutrients and minerals by increased saprophytic activity of Trichoderma in the soil (Ousley et al., 1994). Also, eucalyptus may be exhibit a tendency to accumulate amino acids, proline and sugars, which may be considered as an adaptive mechanism to increase the stress tolerance, and the possibility of eucalyptus phenolic and terpenoid compounds phytotoxicity for plants (El-Darier, 2002), Putnam (1984) reported that Eucalyptus species release volatile compound such as benzoic, cinamic and phenolic acids, which reduce the soil $\mathrm{pH}$.

\section{Head yield and quality \\ Cabbage plants}

Data in Table 4 clear that, total head yield (ton/fed) of cabbage was significantly affected by different treatments as compared with the control in both seasons. Eucalyptus oil treatment causes a significantly increase in total head yield followed by Trichoderma harzianum compared to the control with significant differences in both seasons. These results in agreement with those of Rabeendran et al. (2000), Altintas \& Ball (2005) and Solorzano
- Santos \& Miranda - Novales (2012). Moreover, head diameter and average head weight of cabbage were significantly increased by eucalyptus oils followed by Trichoderma harzianum and Bacillus subtillus in both seasons respectively, without significant differences in between in most cases.

On the other hand plants dipped in distilled water only produced small size and light weight of head cabbage in both seasons. These results are similar to those obtained by Bettial (1995), Rabeendran et al. (2000) and Lucas et al. (2012a). This increase in the total head yield, head diameter and average had weight of cabbage may be a result of increasing weight and number of leaves as well as leaf area (Table 2), such increase with eucalyptus oil treatment followed by Trichoderma harzianum were probably due to reducing or eliminating pathogenic organisms by essential oils and release of soil nutrients and minerals by increasing saprophytic activity of Trichoderma in the soil (Ousley et al., 1994).

\section{Cauliflower plants}

The results in Table 5 clarify that, essential oils and microorganisms significantly improved yield and quality of cauliflower plants compared to control treatment in both seasons. The treatment of eucalyptus oil gave the highest total head yield and average head weight of cauliflower followed by treatment of Trichoderma harzianum compared to other treatments in both seasons. The lowest values of total head yield and average head weight was obtained from control treatment followed by spearmint oil treatment in both seasons respectively. These results are agreed with those obtained by Rabeendran et al. (2000). Head diameter was higher in plants dipped in Trichoderma harzianum, clove oil and Bacillus subtillus compared to other treatments in both 
seasons respectively. The differences were not significant among them in both seasons. On the other hand, the lowest values belonged to control treatment in both seasons. In addition, head height was increased by the eucalyptus oil treatment followed by clove oil treatment compared with the other treatments included control.

TABLE 4. Effect of plant essential oils and microorganisms on head yield and quality of cabbage plants in both seasons.

\begin{tabular}{|l|c|c|c|c|c|c|}
\hline \multirow{2}{*}{ Treatments } & \multicolumn{2}{|c|}{$\begin{array}{c}\text { Average head weight } \\
\text { (kg) }\end{array}$} & \multicolumn{2}{c|}{ Total head yield ton/fed. } & \multicolumn{2}{c|}{$\begin{array}{c}\text { Head diameter } \\
\text { (cm) }\end{array}$} \\
\cline { 2 - 7 } & $\mathbf{2 0 1 4}$ & $\mathbf{2 0 1 5}$ & $\mathbf{2 0 1 4}$ & $\mathbf{2 0 1 5}$ & $\mathbf{2 0 1 4}$ & $\mathbf{2 0 1 5}$ \\
\hline Bacillus subtillus & $3.50 \mathrm{abc}$ & $3.41 \mathrm{bcd}$ & $39.20 \mathrm{c}$ & $38.19 \mathrm{c}$ & $22.80 \mathrm{a}$ & $22.60 \mathrm{ab}$ \\
Trichoderma harzianum & $3.60 \mathrm{ab}$ & $3.61 \mathrm{ab}$ & $40.32 \mathrm{~b}$ & $40.10 \mathrm{~b}$ & $22.90 \mathrm{a}$ & $22.50 \mathrm{~b}$ \\
Eucalyptus oil & $3.71 \mathrm{a}$ & $3.70 \mathrm{a}$ & $41.55 \mathrm{a}$ & $41.44 \mathrm{a}$ & $23.00 \mathrm{a}$ & $22.80 \mathrm{a}$ \\
Spearmint oil & $3.25 \mathrm{~cd}$ & $3.30 \mathrm{~cd}$ & $36.40 \mathrm{de}$ & $36.63 \mathrm{e}$ & $19.51 \mathrm{~d}$ & $20.00 \mathrm{e}$ \\
Clove oil & $3.55 \mathrm{ab}$ & $3.47 \mathrm{bc}$ & $39.76 \mathrm{bc}$ & $38.52 \mathrm{~d}$ & $21.00 \mathrm{c}$ & $20.70 \mathrm{~d}$ \\
Rizolex T50 & $3.31 \mathrm{~b}$ & $3.29 \mathrm{~cd}$ & $36.96 \mathrm{~d}$ & $36.54 \mathrm{e}$ & $22.00 \mathrm{~b}$ & $21.90 \mathrm{c}$ \\
Control & $3.13 \mathrm{~d}$ & $3.23 \mathrm{~d}$ & $35.84 \mathrm{e}$ & $35.69 \mathrm{f}$ & $19.50 \mathrm{~d}$ & $19.70 \mathrm{f}$ \\
\hline
\end{tabular}

TABLE 5. Effect of plant essential oils and microorganisms on head yield and quality of cauliflower plants in both seasons.

\begin{tabular}{|l|c|c|c|c|c|c|c|c|}
\hline \multirow{2}{*}{ Treatments } & \multicolumn{2}{|c|}{$\begin{array}{c}\text { Average head } \\
\text { weight }\end{array}$} & $\begin{array}{c}\text { Total head yield } \\
\text { ton / fed. }\end{array}$ & \multicolumn{2}{c|}{$\begin{array}{c}\text { Head diameter } \\
\text { (cm) }\end{array}$} & \multicolumn{3}{c|}{$\begin{array}{c}\text { Head height } \\
\text { (cm) }\end{array}$} \\
\cline { 2 - 9 } & $\mathbf{2 0 1 4}$ & $\mathbf{2 0 1 5}$ & $\mathbf{2 0 1 4}$ & $\mathbf{2 0 1 5}$ & $\mathbf{2 0 1 4}$ & $\mathbf{2 0 1 5}$ & $\mathbf{2 0 1 4}$ & $\mathbf{2 0 1 5}$ \\
\hline Bacillus subtillus & $993 \mathrm{bc}$ & $1040 \mathrm{c}$ & $7.77 \mathrm{c}$ & $8.00 \mathrm{c}$ & $26 \mathrm{abc}$ & $26.5 \mathrm{abc}$ & $13.0 \mathrm{c}$ & $14.0 \mathrm{~d}$ \\
Trichoderma harzianum & $1044 \mathrm{ab}$ & $1100 \mathrm{~b}$ & $8.16 \mathrm{~b}$ & $8.47 \mathrm{~b}$ & $28 \mathrm{a}$ & $28.0 \mathrm{a}$ & $15.0 \mathrm{bc}$ & $15.6 \mathrm{c}$ \\
Eucalyptus oil & $1114 \mathrm{a}$ & $1150 \mathrm{a}$ & $8.74 \mathrm{a}$ & $8.93 \mathrm{a}$ & $26 \mathrm{abd}$ & $25.9 \mathrm{bcd}$ & $17.5 \mathrm{a}$ & $18.0 \mathrm{a}$ \\
Spearmint oil & $811 \mathrm{~d}$ & $900 \mathrm{e}$ & $6.35 \mathrm{e}$ & $6.93 \mathrm{e}$ & $25 \mathrm{bc}$ & $25.2 \mathrm{~cd}$ & $13.0 \mathrm{c}$ & $14.2 \mathrm{~d}$ \\
Clove oil & $942 \mathrm{bc}$ & $1000 \mathrm{~d}$ & $7.40 \mathrm{~cd}$ & $7.78 \mathrm{~cd}$ & $27 \mathrm{abc}$ & $27.3 \mathrm{ab}$ & $16.0 \mathrm{ab}$ & $16.6 \mathrm{~b}$ \\
Rizolex T50 & $922 \mathrm{c}$ & $970 \mathrm{~d}$ & $7.25 \mathrm{~d}$ & $7.52 \mathrm{~d}$ & $26 \mathrm{abc}$ & $26.0 \mathrm{bcd}$ & $15.0 \mathrm{bc}$ & $15.4 \mathrm{c}$ \\
Control & $808 \mathrm{~d}$ & $850 \mathrm{f}$ & $6.33 \mathrm{e}$ & $6.71 \mathrm{e}$ & $24 \mathrm{c}$ & $24.5 \mathrm{~d}$ & $13.0 \mathrm{c}$ & $14.0 \mathrm{~d}$ \\
\hline
\end{tabular}

Generally, it is clear from Tables 4 and 5 that, the total head yield of cabbage and cauliflower was significantly increased by all treatments compared to control in both seasons. The highest yield harvested from seedlings dipped before planted in eucalyptus oil followed by Trichoderma harzianum treatment, while the lowest yield resulted from control plants. Moreover, cabbage and cauliflower have a large and heavier head when treated with eucalyptus oil and Trichoderma harzianum respectively. These results may be due to the superior effect of both eucalyptus oil and Trichoderma harzianum, which has resulted in increased cabbage and cauliflower vegetative growth characteristics (Table 2 and 3). These results agree with those of Niakan and Saberi (2009), also Cumagun (2012), Rehman et al. (2012), and Hassannejad \& Ghafarbi (2013).
Shelf life period and weight loss Cabbage plants

Data presented in Fig. 1 show that shelf life of cabbage heads was slightly increased by using all studied treatments, the superior treatment was clove oil followed in a descending order by using the treatments of Trichoderma harzianum and Bacillus subtillus as compared with control and other treatments in both seasons. Also, the treatments of eucalyptus oil, spearmint oil, Rizolex T50 and control gave the same values without significant differences among them in both seasons. As for the effect of treatments on weight loss \%, it is clear from Fig. 2 that head weight loss percentage of cabbage was positively affected by treatments in both seasons. The treatment of clove oil showed to be the superior one in reducing head weight loss percentage as compared with control and other treatments in both seasons. On the other 
hand treatment of Rizolex (fungicide) was high loss of head weight followed by control treatment, while other treatment gave intermediate values in this respect in both seasons.

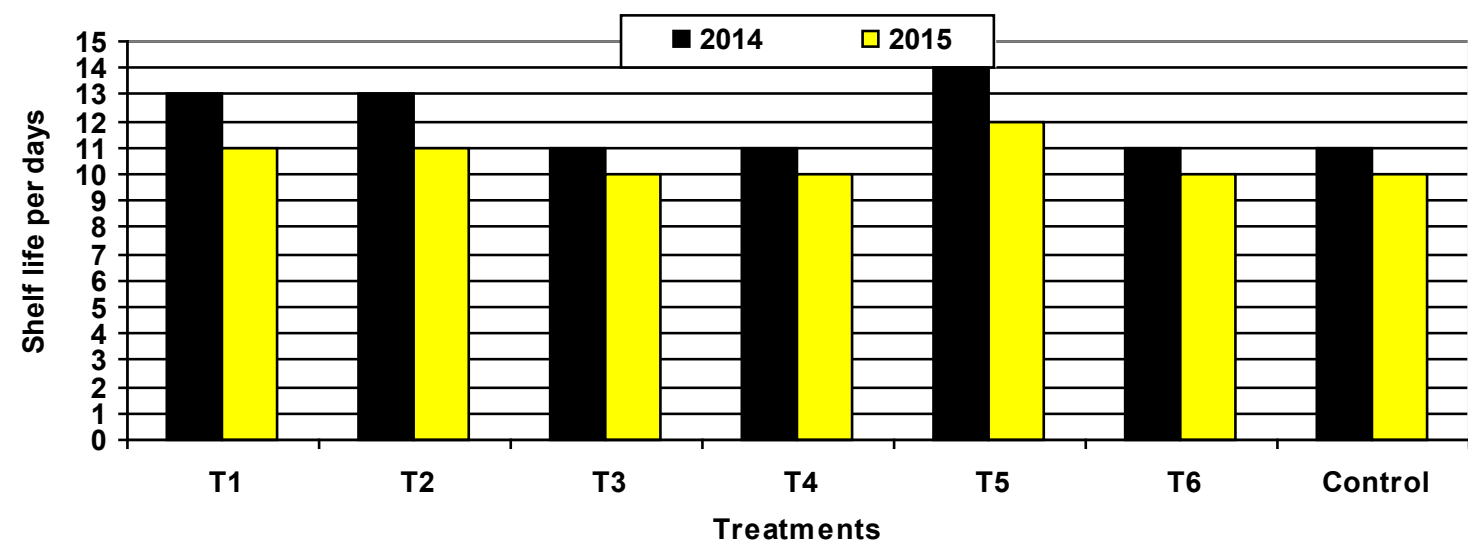

Fig. 1. Effect of plant essential oils and microorganisms on head shelf life (days) of Cabbage plants during 2014 and 2015 seasons.

Where : $\mathrm{T}_{1}$ Bacillus subtillus, $\mathrm{T}_{2}$ Trichoderma harzianum, $\mathrm{T}_{3}$ Eucalyptus oil, $\mathrm{T}_{4}$ Spearmint oil, $\mathrm{T}_{5}$ Clove oil, $\mathrm{T}_{6}$ Rizolex $\mathrm{T}_{50}$ (fungicide) and Control.

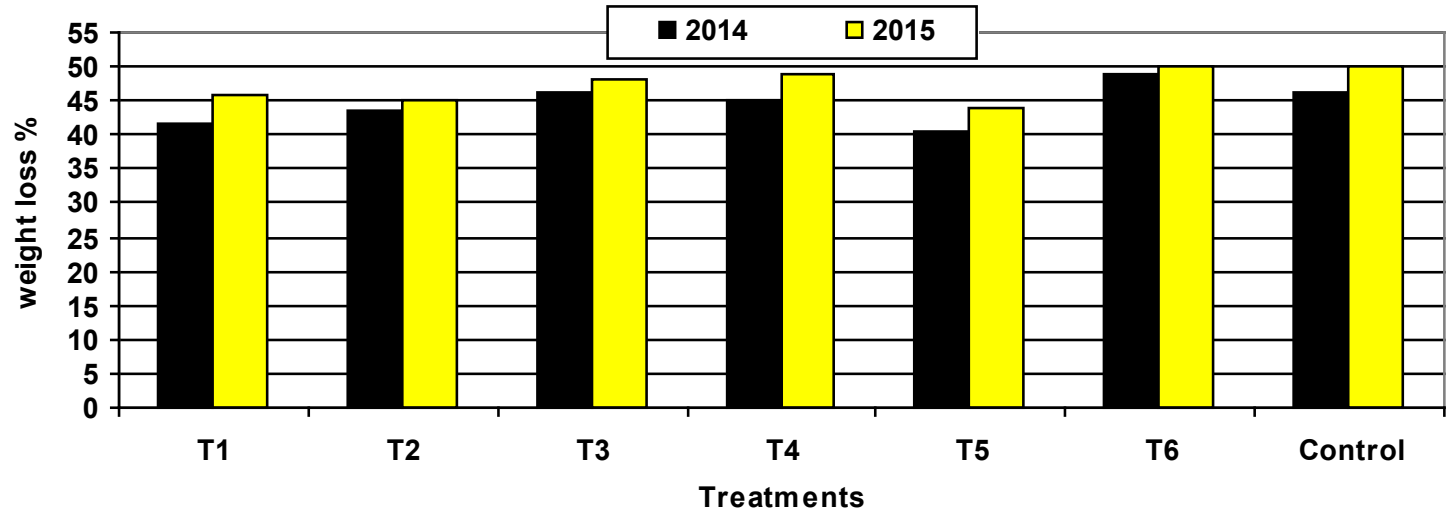

Fig. 2. Effect of plant essential oils and microorganisms on head weight loss \% of Cabbage plants during 2014 and 2015 seasons.

Where : $\mathrm{T}_{1}$ Bacillus subtillus, $\mathrm{T}_{2}$ Trichoderma harzianum, $\mathrm{T}_{3}$ Eucalyptus oil, $\mathrm{T}_{4}$ Spearmint oil, $\mathrm{T}_{5}$ Clove oil, $\mathrm{T}_{6}$ Rizolex $\mathrm{T}_{50}$ (fungicide) and Control .

The loss in head weight is mainly due to water loss as a result of evaporation and transpiration and the amount of dry matter was lost by respiration. This superior of clove oil effects may be due to that it works as a high quality antioxidant and reduces peroxidase enzyme activity (Ponce et al., 2004a, b), reduced the severity of tomato bacterial spot and induced an increase in activities of $\beta$-193glucanase, chitinase and peroxidase (Lucas et al., 2012b).

\section{Cauliflower plants}

Data presented in Fig. 3 revealed that all treatments were slightly affected on head shelf life of cauliflower in both seasons. Treatment of Trichoderma harzianum increased one or two days as compared with control and other treatments in both seasons. Moreover, the treatments of eucalyptus oil, clove oil, Rizolex T50 and control gave the same values without significant differences among them in both seasons. Also, it is clear from Fig. 4 that head weight loss percentage of cauliflower was significantly 
decreasing by treatments, the superior treatment was Trichoderma harzianum compared to control and other treatments in both seasons, these results are agree to those obtained by Bettial (1995).

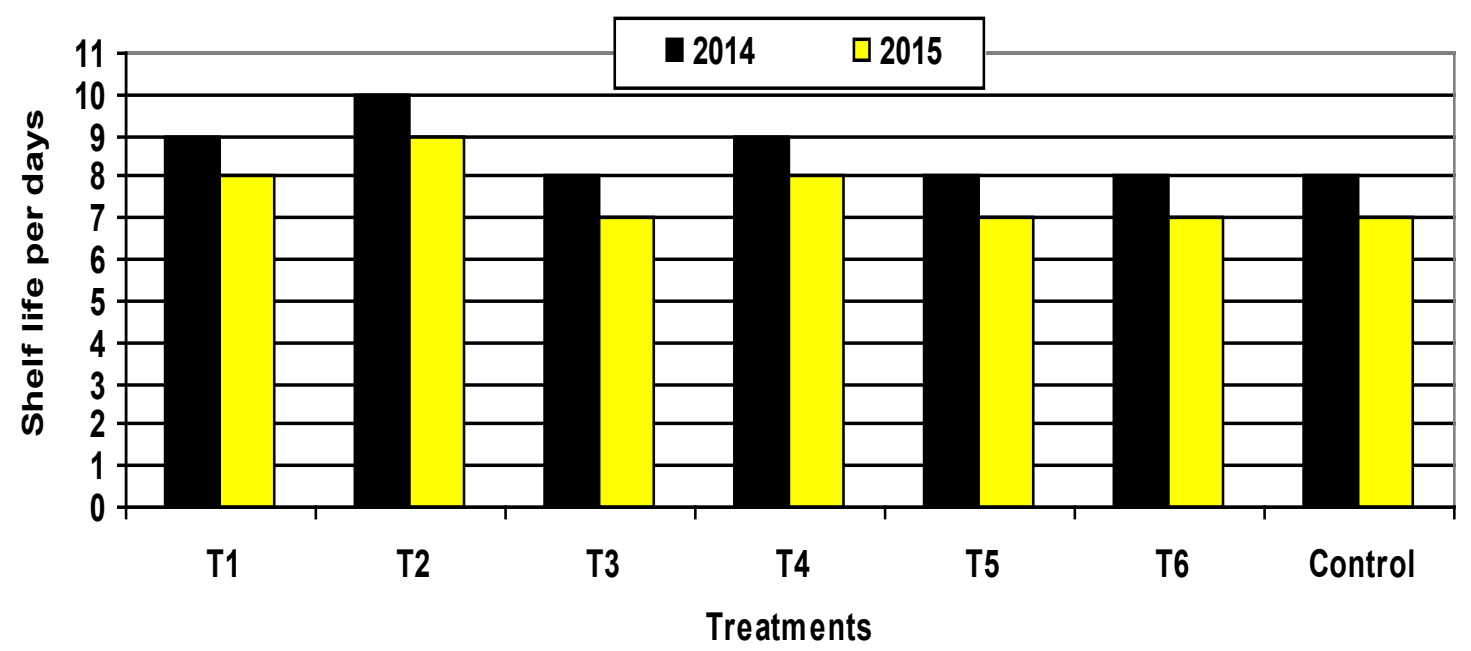

Fig. 3. Effect of plant essential oils and microorganisms on head shelf life (days) of Cauliflower plants during 2014 and 2015 seasons.

Where : $\mathrm{T}_{1}$ Bacillus subtillus, $\mathrm{T}_{2}$ Trichoderma harzianum, $\mathrm{T}_{3}$ Eucalyptus oil, $\mathrm{T}_{4}$ Spearmint oil, $\mathrm{T}_{5}$ Clove oil, $\mathrm{T}_{6}$ Rizolex $\mathrm{T}_{50}$ (fungicide) and Control

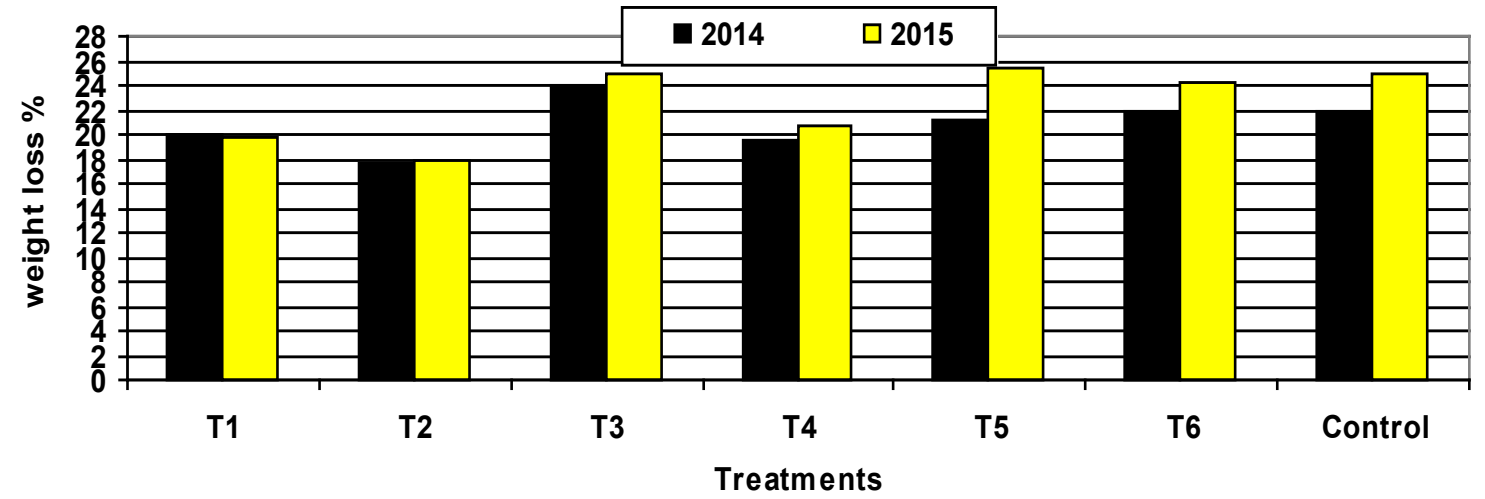

Fig. 4. Effect of plant essential oils and microorganisms on head weight loss \% of cauliflower plants during 2014 and 2015 seasons.

Where : $\mathrm{T}_{1}$ Bacillus subtillus, $\mathrm{T}_{2}$ Trichoderma harzianum, $\mathrm{T}_{3}$ Eucalyptus oil, $\mathrm{T}_{4}$ Spearmint oil, $\mathrm{T}_{5}$ Clove oil, $\mathrm{T}_{6}$ Rizolex $\mathrm{T}_{50}$ (fungicide) and Control.

\section{Assessment of diseases percentage}

It is clear from Tables 6 and 7 that, both of bio-agents and oils under field condition improved transplants survival and reduced the dampingoff disease incidence as compared to untreated control. Bio-agents, clove oil and Rizolex T50 were recorded significant reduction of cabbage damping-off at the first season. At the same time all treatments reduced it for cauliflower plants. This season it was observed symptoms of leaf spots. All treatments were effective in decreasing leaf spot severity significantly as compared to control. The result were in agreement with Islam \& Faruq (2008), Roy et al. (1998), Faruk et al. (2002) and Champawat \& Shama (2003) who employed bio-control agents for the disease 
control and revealed the inhibitory effect was probably due to hyerparasitism/ mycoparasitism, competition for space and nutritional source and antagonistic chemicals produced and released into the environment. Trichoderma sp., have been reported to produce antibiotic compounds (Trichodermin) extracellular enzymes (chitinase, cellulose) unsaturated monobasic acids (Dermadine) and peptides that either damage plant pathogen or enhance their population in biota. Furthermore, Juglal et al. (2002) studied the effectiveness of nine essential oils to control the growth of mycotoxins producing moulds and noted that, clove, cinnamon and oregano were able to prevent the growth of Aspergillus parasiticus and Fusarium moniliforme. Furthermore, El-Mougy et al. (2007) reported that geranium, rose, lem $\neg$ on and mint essential oils were tested as seed coating and/ or foliar spray. A significant reduction in root rots and wilt incidence of bean at both preand post-emergence stages under greenhouse conditions. Application of essential oil is a very attractive method for controlling plant diseases. Essential oils and their components are gaining increasing interest because of their relatively safe status, their wide acceptance by consumers, and their exploitation for potential multi-purpose functional uses (Ormancey et al., 2001).

TABLE 6. Bio-efficacy of some plant essential oils and bio-agents for management cabbage and cauliflower diseases during 2014 season.

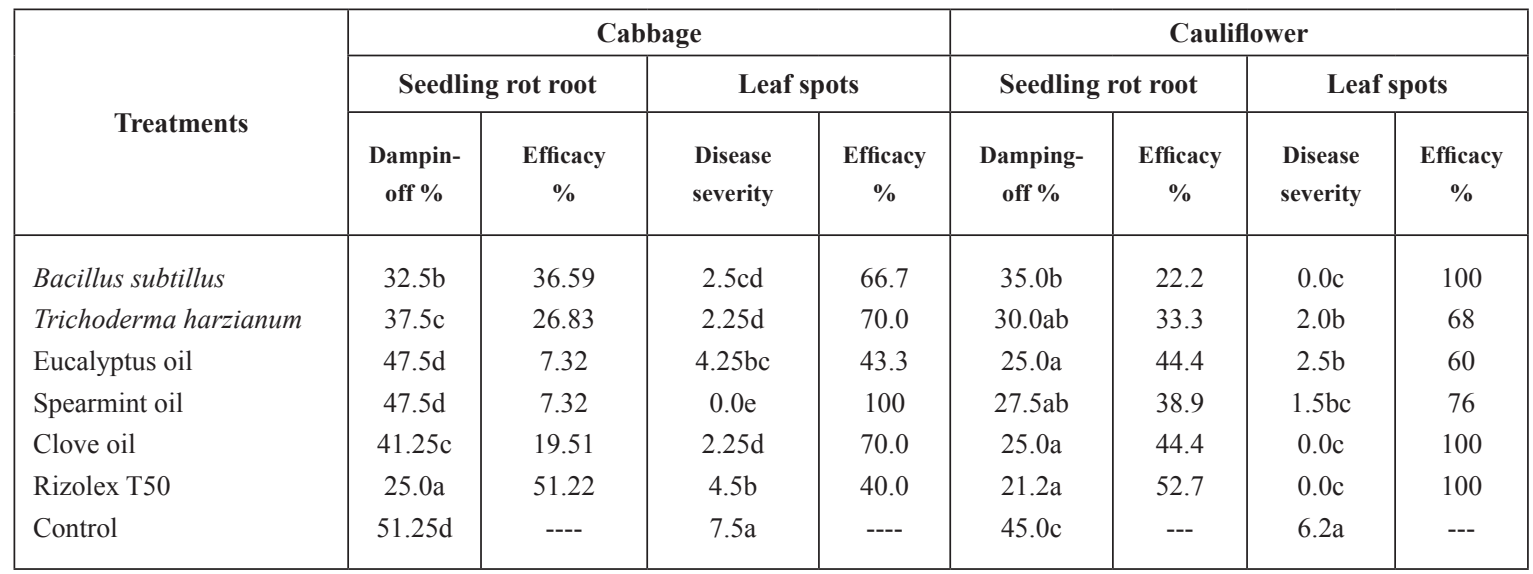

TABLE 7. Bio-efficacy of some plant essential oils and bio-agents for management cabbage and cauliflower diseases during $201^{\circ}$ season.

\begin{tabular}{|c|c|c|c|c|c|c|c|c|}
\hline \multirow{3}{*}{ Treatments } & \multicolumn{4}{|c|}{ Cabbage } & \multicolumn{4}{|c|}{ Cauliflower } \\
\hline & \multicolumn{2}{|c|}{ Seedling rot root } & \multicolumn{2}{|c|}{ Downy mildew } & \multicolumn{2}{|c|}{ Seedling rot root } & \multicolumn{2}{|c|}{ Downy mildew } \\
\hline & $\begin{array}{c}\text { Damping } \\
\text {-off } \%\end{array}$ & $\begin{array}{c}\text { Efficacy } \\
\%\end{array}$ & $\begin{array}{l}\text { Disease } \\
\text { severity }\end{array}$ & $\begin{array}{c}\text { Efficacy } \\
\%\end{array}$ & $\begin{array}{c}\text { Damping- } \\
\text { off } \%\end{array}$ & $\begin{array}{c}\text { Efficacy } \\
\%\end{array}$ & $\begin{array}{l}\text { Disease } \\
\text { severity }\end{array}$ & $\begin{array}{c}\text { Efficacy } \\
\%\end{array}$ \\
\hline Bacillus subtillus & $8.75 \mathrm{ab}$ & 87.50 & $4.0 \mathrm{bc}$ & 68.0 & $17.50 \mathrm{a}$ & 36.36 & $1.25 \mathrm{~b}$ & 83.3 \\
\hline Trichoderma harzianum & $17.50 \mathrm{c}$ & 78.57 & $5.0 \mathrm{~b}$ & 60.0 & $16.25 \mathrm{a}$ & 40.91 & $1.25 \mathrm{~b}$ & 83.3 \\
\hline Eucalyptus oil & $13.75 b c$ & 60.71 & $2.25 \mathrm{c}$ & 82.0 & $27.50 \mathrm{~b}$ & 00.00 & $1.5 \mathrm{~b}$ & 80.0 \\
\hline Spearmint oil & $3.75 \mathrm{a}$ & 89.29 & $2.0 \mathrm{c}$ & 84.0 & $31.25 \mathrm{~b}$ & -13.63 & $1.5 \mathrm{~b}$ & 80.0 \\
\hline Clove oil & $5.00 \mathrm{a}$ & 85.71 & $3.5 \mathrm{bc}$ & 72.0 & $28.75 b$ & -4.54 & $2.0 \mathrm{~b}$ & 73.3 \\
\hline Rizolex T50 & $6.25 \mathrm{ab}$ & 82.14 & $4.0 \mathrm{bc}$ & 68.0 & $15.00 \mathrm{a}$ & 45.45 & $2.75 b$ & 63.3 \\
\hline Control & $35.00 \mathrm{~d}$ & -- & $12.5 \mathrm{a}$ & --- & $27.50 \mathrm{~b}$ & -- & $7.5 \mathrm{a}$ & -- \\
\hline
\end{tabular}




\section{Conclusions}

It can be concluded that, dipping the seedlings of cabbage and cauliflower in Eucalyptus oil $(1 \mathrm{ml}$ of oil// water) or fungal Trichoderma (Trichoderma arzianum) suspensions (spore concentration of $10^{6}-$ $10^{7} / \mathrm{ml}$ ) for 30 minutes before transplanting caused improving at vegetative growth, total head yield with large and heavier heads. The treatment with fungal Trichoderma mostly increased shelf life period and decreased weight loss percentage of cabbage and cauliflower heads. Microorganisms and essential oils under field conditions could be improved transplants survive and reduced the damping-off disease incidence as compared to untreated control.

\section{References}

Altintas, S. and Ball, U. (2005) Application of Trichoderma harzianum increases yield in cucumber (Cucumis sativus) grown in an unheated glasshouse. J. Appl. Hort., 7, $25-28$.

Azarmi, R., Hajieghrari, B. and Giglou, A. (2011) Effect of Trichoderma isolates on tomato seedling growth response and nutrient uptake. African J. Bio., 10 (31), 5850-5855.

Baker, R. (1988) Trichoderma spp. as plant stimulants. Critical Reviews in Biotechnology, 7, 97-106.

Ball, U. and Altintas, S. (2006) Effect of Trichoderma harzianum on yield and fruit quality characteristics of tomato (Lycopersicon esculentum Mill) grown in an unheated greenhouse. Aust. J. Exp. Agric., 46 (1), 131 -136 .

Bettial, W. (1995) Selective isolation of Bacillus. In: Melo, I.S.de \& Sanhueza, R.M.V. (cords). Methods of selection of microorganisms antagonistic to plant pathogens. Jaguariuna: EMBRAPA-CNPMA, Manual Tecnico. pp. $35-36$.

Champawat, R.S. and Sharma, R.S. (2003) Integrated management of nursery disease in Brinjal Chilli cabbage and onion. J. Myco. Plant Patho., 33 (2), 290 $-291$.

Cumagun, G.J.R. (2012) Managing plant diseases and promoting sustainability and productivity with Trichoderma: The Philippine Experience. J. Agric. Sci. Tech., 14, $699-714$.

Dey, T.K. (2005) Effect of soil solarization in controlling damping-off disease of true potato seedlings. Bangladesh J. Plant Path., 21 (1 \& 2), 93.
Elad, Y., Chet, I. and Henis, Y. (2006) Biological control of Rhizoctonia solani in strawberry fields by Trichoderma harzianum. Plant \& soil, 60, $245-254$.

El-Darier, S.M. (2002) Allelopathic effects of eucalyptus rostrata on growth, nutrient uptake and metabolite accumulation of Vicia faba L. and Zea mays L. Pakistan J. Bio. Sci., 5 (1), 6-11.

El-Mougy, N.S., El-Gamal, N.G. and Abdel-Kader, M.M. (2007) Control of wilt and root rot incidence in Phaseolus vulgaris L. by some volatile compounds. J. Plant Protec. Res., 47 (3), 255 - 265.

Faruk, M.I., Rahman, M.L. and Bari, M.A. (2002) Management of seedling disease of cabbage through Trichoderma harzianum amendment in seedbed. Bangladesh J. Plant Patho, 18 (1-2), 49 - 53.

Francisco, M., Tortosa, M., Martinez-Ballesta, M.C, Velasco, P., Garcia-Viguera, C. and Moreno, D.A. (2017) Nutritional and phytochemical value of Brassica crops from the agri-food perspective. Annals Appli. Bio., 170 (2), 273-285.

Hassannejad, S. and Ghafarbi, S.P. (2013) Allelopathic effects of some Lamiaceae on seed germination and seedling growth of dodder (Cuscuta campestris Yunck). Inter. J. Biosci., 3 (3), 9 - 14.

Hossain, M.T. (2010) Survey on major diseases of vegetable and fruit crops in Chittagong region. Bangladesh J. Agric. Res., 35 (3), 423 - 429.

Islam, M.T. and Faruq, A.N. (2008) Effect of selected soil amendments on seed germination, seedling growth and control of damping-off of chilli seedlings. $J$. Sher-e-Bangla Agric. Univ., 2 (2), 12 - 16.

Juglal, S., Govinden R. and Odhav B. (2002) Spices oils for the control of co-occurring mycotoxin-producing fungi. J. Food Protect., 65, 638-687.

Kaveh, H., Vatandoost, S., Aroiee, H. and Mazhabi, M. (2011) Would Trichoderma affect seed germination and seedling quality of two muskmelon cultivars, khatooni and qasri and increase their transplanting success. J. Bio. Environ., 5 (15), 169 - 175.

Lindberg, C.H., Melathopoulos, A.P. and Winston, M.L. (2000) Laboratory evaluation of miticides to control Varroa jacobsoni (Acari: Varroidae), a honey bee (Hymentoptera: Apiae) Parasite. J. Econ. Entom., 93, 189 - 198. 
Lucas, G.C., Alves, E., Pereira, R.B., Zacaroni, A.B., Perina, F.J. and Souza, R.M. (2012a) Indian clove essential oil in the control of tomato bacterial spot. $J$. Plant Path., 94, 45 - 51.

Lucas, G.C., Alves, E., Pereira, R.B., Perina, F.J. and Souza, R.M. (2012b) Antibacterial activity of essential oil on Xanthomonas vesicatoria and control of bacterial spot in tomato. Pesq. agropec. bras., Brasilia, 47 (3), 351-359.

Niakan, N. and Saberi, K. (2009) Effects of Eucalyptus allelopathy on growth characters and antioxidant enzymes activity in Phalaris weed. Asian J. Plant Sci., $8(6), 440-446$.

Ormancey, X., Sisalli, S. and Coutiere, P. (2001) Formulation of essential oils in functional perfumery. Parfums, Cosmetiques, Actualites, 157, 30 - 40.

Ousley, M.A., Lynch, J.M. and Whipps, I.M. (1993) Effect of Trichoderma on plant growth a balance between inhibition and growth promotion. Microb. Ecol., 26, 277-285.

Ousley, M.A., Lynch, J.M. and Whipps, I.M. (1994) Effect of addition of Trichoderma inocula on flowering and shoot growth of bedding plants. Scienciat Hort., 59, 147-155.

Park, S., Arasu, M.V., Jiang, N., Choi, S.H., Lim, Y.P. and Park, J.T. (2014) Metabolite profiling of phenolics, anthocyanins and flavonols in cabbage (Brassica oleracea var. capitata). Indust. Crops \& Products, 60, $8-14$.

Pereira, R.B, Lucas, G.C., Perina, F.J., Resende, M.L. and Alves, E. (2011) Potential of essential oils for the control of brown eye spot in coffee plants. Cienciae Agrotecnologia, 35, 115 - 123.

Ponce, G., del Valle C. and Roura S.I. (2004a) Shelf life of leafy vegetables treated with natural essential oils. $J$. food Sci., 69 (2), 50-56.

Ponce, G., del Valle, C. and Roura, S.I. (2004b) Natural essential oils as reducing agents of peroxidase activity in leafy vegetables. LWT. Food Sci. \& Techno., 37 (2), 199-204.

Prakah, A. and Rao, J. (1997) Botanical pesticides in agriculture. CRC press, Florida, USA p: 461.
Putnam, A.R. (1984) Allelopathic chemicals. Can natural plant herbicides help control weeds. Weeds Today 15, 6-8.

Rabeendran, N., Moot, D.J., Jones, E.E. and Stewart, A. (2000) Inconsistent growth promotion of cabbage and lettuce from Trichoderma isolates. New Zealand Plant Protect., 53, 143 - 146.

Rehman, U.S., Lowrence, R., Kumar, E.J. and Badri, Z.A. (2012) Comparative efficacy of Trichoderma viride, T. harzianum and Carbendazim against damping-off disease of cauliflower caused by Rhizoctonia solani kuehn. J. Bio. Pest., 5 (1), 23 $-27$.

Roy, S.K., Das, B.C. and Bora, L.C. (1998) Nonpesticidal management of damping off of cabbage and cauliflower caused by Rhizoctonia solani Kuehn. J. Agric. Sci. Society, 11 (2), 127 - 130.

Seema, M. and Devaki, N.S. (2010) Effect of some essential oils on Rhizoctonia solani Kuhn infecting flue-cured Virginia tobacco. J. Bio., 3 (3), 563 566.

Snedecor, G.W. and Cochran, W.G. (1990) "Statistical Methods". $7^{\text {th }}$ ed., Iowa State Univ. Press. Ames., Iowa, USA, p. 593.

Solorzano-Santos, F. and Miranda-Novales, M.G. (2012) Essential oils from aromatic herbs as antimicrobial agents. Food Bio. Plant Bio., 23 (2), $136-141$.

Talekar, N.S. and Shelton, A.M. (1993) Biology, ecology and management of the diamondback moth. Annual Rev. Entomo., 38, 275 - 302.

Taylor, E. and Francis, L. (1998) Trichoderma and Glioclandium. Phytopathology, 1, 139 - 191.

Wasfi, M.T., Shendy, A.S. and Gadalla, S.A. (2016) Chronic exposure of insecticide and fungicide as indicator of health impact in some commonly consumed leafy vegetables: Case study. Food \& Agric., 2, 119-126.

Windham, M.T., Elad, Y. and Baker, R. (1986) A mechanism for increased plant growth induced by Trichoderma spp. Phytopathology, 6, 518-521. 
Yamaguchi, M. (1983) World vegetables, principles, production and nutritive values. Ellis Horwood Limited Publishers, 415 p.

\section{تأثير المحسنات البيولوجية والزيوت النباتية على نمو و جودة وإنتاجية نباتات الكرنب

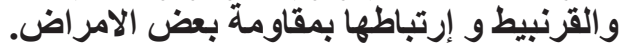

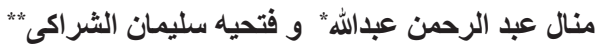

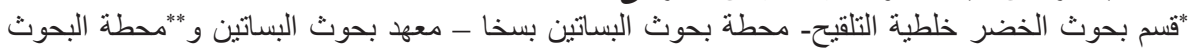 الزر اعيه بسخاــ معهد بحوث امر اض النبات ــــة مركز البحوث الزر اعية ــ القاهرة ـ مصر.}

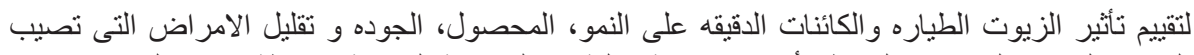

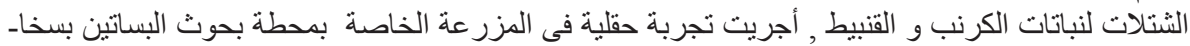

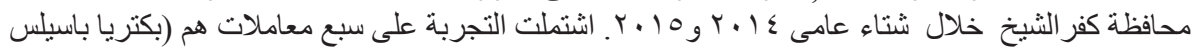
Bacillus subtillus

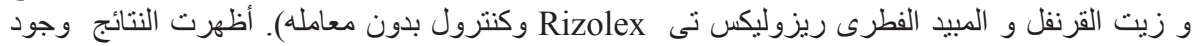

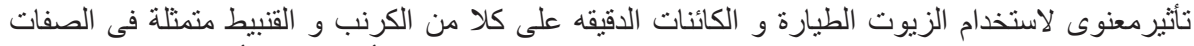

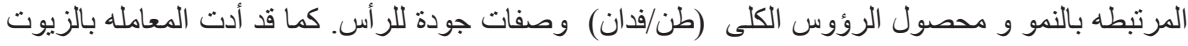

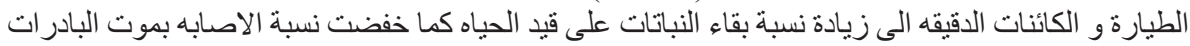

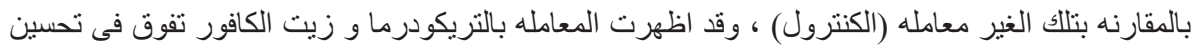

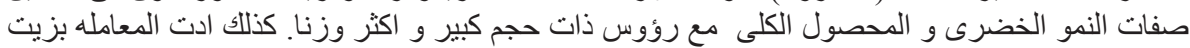

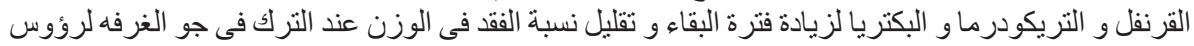

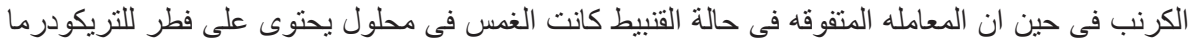

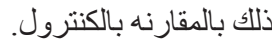

